\title{
Freedom of Press and Media Ethics: A Comparative Study
}

\author{
Shobha Chaudhary ${ }^{1}$, Dr. Ritesh Chaudhary ${ }^{2 *}$ \\ ${ }^{I}$ Department of Mass Communication Khawaja Moinuddin Chishti Language University, Lucknow \\ ${ }^{2}$ School of Media, Journalism \& Film Making Himgiri Zee University, Dehradun
}

*Corresponding Author: Dr. Ritesh Chaudhary, School of Media, Journalism \& Film Making Himgiri Zee University, Dehradun

\begin{abstract}
If there is a first stage of freedom in any country, then it is the freedom of expression. If the person will not have the freedom to speak, then surely there is no other freedom for him. The right to express itself gives birth to all other rights. The whole world looks at the media to have access the true and correct information. But with the increase of Paid News and Yellow Journalism, the legitimacy of information given by media is vulnerable. As the unethical characters are coming out of the media industry and forced the policy makers to think about it to introduce new laws and regulations to maintain its place in the hearts of common man. Section 19-1 (a) of constitution tells us about the freedom of speech but one has to be very clear about the use of these rights given. If we fail to do so then needs arise to put cap on that, which is inhuman and unethical as this deprives one to access its rights.
\end{abstract}

Keywords: Freedom of press, Indian constitution, Article 19(a), democracy.

\section{INTRODUCTION}

When we talk about media and freedom of press, then it is crucial to note down that the constitution of India has provided nothing in this regard. In general, Freedom of the press has a wide meaning. It is not limited to any organization or community, but the freedom of the press means the freedom of the individual. The question is also that what is the freedom of the press? How the freedom of the press can be defined? So the freedom that the constitution talks about is the right to speak and act on its own free will. The freedom given to the press under the Constitution of India is not special. The press has the right to express itself like any common person does. The governments of any country are keen that they can control the media there. But constitutionally elected governments in India do not have the right to control the media. Because if the government takes the media under its own control then it will be a step weaken the democracy.

In 1976, the Congress government in India passed legislation from the following house to enact the publication of the Offensive Matter Act. This was a period of emergency; at this time the intention of the government was to control the media. But two years later, in 1978, the newly elected Janata Dal government abolished this law. However, this year the $44^{\text {th }}$ amendment to the Constitution of India gave the House the right to regulate the freedom of the press. For this, Article 361 (A) was amended in the Constitution. Freedom of expression of the Principal Rights in Fundamental Rights in Part Three, called the soul of the constitution, ensures that "every person can say what he says without any pressure and accept the talk of others without any pressure." The press must always work to strengthen the sovereignty of the nation as well as its integrity. It means that the duty of the media is to create an environment based on your information that teaches people to live in unity and harmony.

In Romesh Thapar v/s State of Madras, Chief Justice Patanjali Shastri said, 'The most important thing for any organization of democracy is freedom of expression. Unless there is an independent discussion in the society, the society will not develop.'

In Indian Express v. Union of India, it has been held that the role of media is important in this democratic process, its importance cannot be ignored. The freedom of media is ensured by three main things: the media is able to access the source of any information, it has the freedom to disclose information, it has the freedom to operate a media group.

The country has witnessed such instances where it has tried to suppress the voice of the media. In such circumstances, the judiciary has control. In one such case, Brij Bhushan v. State of Delhi (AIR 
1950 SC 129), various information was sought regarding the publication of English weekly to be published from Delhi, the capital of India. Keeping in mind the freedom of the press, the court repealed section 7 of the Punjab (Eastern) Security Act, which was passed in the year 1949, in which provision for pre-publication permission was given in communal matters. The important aspect for freedom of expression is: Freedom of speech for development, Freedom of open discussions to discover the truth, Freedom to play an active role in democracy, Freedom to speak in political matters.

Media ethics is the subdivision of applied ethics dealing with the specific ethical principles and standards of media, including broadcast media, film, theatre, the arts, print media and the internet. The field covers many varied and highly controversial topics, ranging from war journalism to Benetton advertising. It is the responsibility of the media to create an atmosphere in their country and society to develop a sense of social harmony, but it is seen in most of the cases that social dissemination is born as a result of the news broadcast by the media. The media seems to run away from its social responsibilities. Today, most of the media is only fulfilling its business responsibilities but this media is far behind in discharging its social responsibilities. In 2016, a minor girl attempted self-immolation in front of Uttar Pradesh Legislative Assembly. The reason was the harassment of the girl by antisocial elements. The police remained silent in this case, the girl's report was not recorded. The girl, in her unhappiness, tried to self-immolate in front of the Vidhan Sabha. The media, while discharging their professional responsibility, took pictures of her and captured the incident on her camera, but not a single journalist came forward to help the woman.

The ethics of journalism is one of the most well-defined branches of media ethics, primarily because it is frequently taught in schools of journalism. Journalistic ethics tends to dominate media ethics, sometimes almost to the exclusion of other areas. Topics covered by journalism ethics include: News manipulation, Truth, Public interest, Privacy, Fantasy, Taste, Conflict with the law. It has been seen in most of the cases that the trend of investigative journalism in the media is over. Paid news is the reason for this. Today, when it is the time for fake news, it would probably be wrong to expect from the media that they should put the ideal situation before us. Today, when media has become a pure business, it has become necessary for him to transmit information of his own benefit from public interest. Many attempts are made to show the mirror to the media but they have no effect. To what extent is the lie, fake news and misleading news coming on social media a matter of concern. Is it right to put society and country in peril in the name of freedom of expression? This is a burning subject, but no one is able to discuss it. Media work is not just to give information but to awaken and inspire the society. Protection of values and promotion of India's interests is the moral responsibility of the media. But today, the news of 'Riya and Sushant Singh' is important for the media in the country and issues related to public interest are getting away from the media. The state of Indian media is continuously falling in the world scene. Its place has been counted in the list of countries in the last rows of the world. This situation is terrible for a democracy like India.

Akhbar Allahbadi said in reference to the media, 'Khincho Na Kamaan Ko, Na Talwaar Nikalo, Jab Taup Ho Mukabil, Tab Akhbaar Nikalo' The real meaning of the above poetry is that the, 'Do not pull the commands or draw the sword, Take out the newspaper when the cannon fights'. This couplet of Akbar Allahabadi was enough before independence to explain what the power of media words can be. The words of the media were those who had the power to compete with sword and weapon. But the media fell from its moral responsibilities and the changing era reversed the words of Akbar Allahabadi for the media. Today, these lines will be more accurate for the media, 'Khincho $\mathrm{Na}$ Mukhato Ko, Khud Mukhata Laga Lo, Naam Daam Samman Chahiye, To Akhbaar Nikalo' means 'Do not put your mouths, not your mouths, if you want name and honor, then take out the newspaper.'

Media information has a wide impact. If the media gives misleading information, then it can definitely play an explosive role in society. Media false information or misinformation can damage a person's reputation. Social reputation is not a one-day earning thing. It takes a life to earn, and a mistake in the media can end a person's lifetime earnings. It does not make up. Therefore, it becomes very necessary that the media should take full information before publishing programs of this way. But today it is unfortunate that in the matter of showing the first and fastest news, who cares about it. The media is not only damaging the image of the individual but it also damages the reputation of the institutions. Accused the High Court judge wrongly. The allegation against the Judge was that he had acquired some land at a low price misusing his office, but the inquiries revealed that he had acquired the land not in any discretionary quota but in the open market at the market price. However, media 
responsibility is also important. It is possible that the news media is presenting it is wrong or not true. Incomplete truth can be harmful to society. It is said that half incomplete truth can be more dangerous than false. The media also twists and presents facts in a sensational manner. To get full respect for the media, one has to understand that the trust of the society should not be removed from it.

Suppose there is a constitutional system in India that a person will have freedom of expression but this is not an absolute right. Because the freedom of expression may harm another. Article 19 (2) of the Constitution of India includes several conditions such as security of the state, friendly relations with foreign states, public order, decency and morality, contempt of court, defamation, antitrust a crime and a threat to India's sovereignty and integrity, has imposed some restrictions on free speech. Which is also necessary. Because freedom of expression does not mean that the person should defame another or let the freedom in the internal and external affairs of the country reach freely.

The press freedom index that Reporters without Borders publishes every year measures the level of freedom of information. It reflects the degree of freedom that journalists, news organizations and citizens enjoy in each country, and the efforts made by the authorities to respect and ensure respect for this freedom. In a report published Wednesday, Reporters Without Borders, a Paris-based non-profit, ranked India $140^{\text {th }}$ out of 180 countries surveyed for the free speech it affords the media. This was a one-point jump from the country's 2013 ranking, when it recorded its steepest fall on the annual-list since 2002. The 2014 list was topped by Finland for at least the third time in a row, followed by the Netherlands, Norway and Luxemburg. India fared better than neighbors Pakistan $\left(158^{\text {th }}\right)$, Sri Lanka $\left(165^{\text {th }}\right)$ and China $\left(175^{\text {th }}\right)$, but ranked lower than countries such as Afghanistan $\left(128^{\text {th }}\right)$ and Bangladesh $\left(146^{\text {th }}\right)$ Eritrea, a small country in the Horn of Africa, had the worst rating at $180^{\text {th }}$ in this year's list. This year India was ranked 136 out of 180 countries in the World Press Freedom Index. It's a small improvement form 2014, 2013 and 2012, when India was ranked 140 each year, but a disaster if we look at the statics from the year 2010 or 2009 , where India was ranked $122^{\text {nd }}$ and $105^{\text {th }}$, respectively.

\section{CONCLUSION}

There was a time when the media acted as a watchdog of democracy. Today, true journalism has become a rare spectacle. Media ethics became an oxymoron now days, which means it is a phrase that combines two apparently contradictory ideas. The image of the journalist in India has taken quite a battering. The media has a significant role in devising the public opinion, but it has consistently ignored the major issues the nations facing, such as poverty, corruption, health, education and raging communalism and concentrating only on news that increases readership and viewership. Customized and profit-oriented journalism have come to replace spirited journalism. If the fourth estate has lost its prominent position, it is because of a paradigm shift in the priorities of reporting, driven by corporate interests. Many sections have a clear corporate agenda, for which they create news and do a partisan analysis based on false information. This tendency is stronger in the regional press. Language is the lens through which journalists report to the public on news developments. All too often, journalists get their lens, their language, from the corporate and government authority or their own national allegiances.

Media has played an important role in social as well as political change in a democratic country like India. The media has played an important role in all of them, be it the case of farmers committing suicide or the safety of daughters in the country. The media has achieved a better place in becoming the voice of the poor of the country. For this the praise of the media of India is less. The media has also raised its voice against the politicians, in their corruption cases. It is the responsibility of the media to maintain the trust of the common man. I conclude by quoting of the famous Urdu poet Faiz:

\section{'Gulon Mein Rang Bhare Baad-E-Naubahaar Chale, \\ Chale Bhi Aao Ki Gulshan Ka Kaarobaar Chale.’}

The real meaning of the above poetry is that the objective situation in the country is ripe, and calls the patriotic people to come forward to serve the country.

\section{REFERENCES}

[1] Thakurta Paranjoy Guha (2010): Cut-Rate Democracy Outlook, Weekly news magazine, Anniversary special on Media in crises: Essays, November 2010.

[2] DD Basu, Introduction to the Constitution of India, LexisNexis, ISBN: 9789388548861

[3] Romesh Thapar v. State of Madras, AIR 1950 SC 124. 
[4] Indian Express v. Union of India, (1985) 1 SCC 641.

[5] https://indiankanoon.org/doc/43023/

[6] Sat Dev Verma, The Punjab Security of Land Tenures: Punjab Act X of 1953

[7] Noam Chomsky (Nov 2010, Outlook): Telephonic interview with Outlook magazine on its $15^{\text {th }}$ anniversary special issue

[8] Rusbridger, Alan. (Sep 19, 2010 Hindu): He delivered a lecture on 'The future of journalism in the digital age, organized by The Hindu and the Asian College of Journalism at Chennai.

[9] DD Basu, Introduction to the Constitution of India, LexisNexis, ISBN: 9789388548861

[10] Joseph Pulitzer (Vidura, Oct-Dec, 2005): Quoted by VirBala Aggarvial article 'Challenges and opportunities of press freedom' ViduraPII, New Delhi.

[11] Faiz wrote this ghazal on 29 January 1954, in the Montgomery confinement of Rawalpindi.

Citation: Shobha Chaudhary, Dr. Ritesh Chaudhary. "Freedom of Press and Media Ethics: A Comparative Study". International Journal of Media, Journalism and Mass Communications (IJMJMC), vol 6, no. 4, 2020, pp. 20-23 doi: http://dx.doi.org/10.20431/2454-9479.0604003.

Copyright: (C) 2020 Authors. This is an open-access article distributed under the terms of the Creative Commons Attribution License, which permits unrestricted use, distribution, and reproduction in any medium, provided the original author and source are credited. 